\title{
NPP-ID: Non-Pollen Palynomorph Image Database as a research and educational platform
}

\author{
Lyudmila S. Shumilovskikh ${ }^{1,2}\left(\right.$ E) Elena S. Shumilovskikh ${ }^{2} \cdot$ Frank Schlütz $^{1,3}{ }^{(1)} \cdot$ Bas van Geel $^{4}(\mathbb{D}$
}

Received: 3 June 2021 / Accepted: 9 June 2021 / Published online: 30 August 2021

(C) The Author(s) 2021

\begin{abstract}
Non-pollen palynomorphs (NPPs) form a large group of biological objects found in palynological slides besides pollen grains. This includes various remains of algae and fungi, shells, resting stages and eggs of invertebrates, among others. Publications of NPP-types started in the 1970s with studies of BvG and colleagues, and large numbers of new types continue to be published every year. For an overview of this diverse world of "extra fossils", we created the Non-Pollen Palynomorph Image Database (NPP-ID) to gather NPP knowledge, structured by acronyms and known taxonomy to assist identification and palaeoecological interpretation (https://nonpollenpalynomorphs.tsu.ru/). An integral part is a database of illustrations, descriptions and ecological background of NPPs. While numerical data are routinely stored in open access repositories, the NPP-ID enables the definitions, identification and interpretation of the NPP taxa to be shared. The NPP-ID operates as an open research project aiming to provide open access to descriptions and illustrations of NPPs. However, due to publication rights, access to some original images is restricted and registration by users is required. We encourage palynologists to contribute to the further growth of the database by uploading their own microphotographs or drawings under an open access license. Contributors will be acknowledged by co-authorship in publications on updates of the NPP-ID.
\end{abstract}

Keywords Palynology $\cdot$ Fungal remains $\cdot$ Algal remains $\cdot$ Unknown palynomorphs $\cdot$ Identification tool

\section{Motivation}

Non-pollen palynomorphs (NPPs) form a large group of microscopic remains found in palynological slides besides pollen. Such microfossils have received attention since the very beginning of palynology (Rudolph 1917; Hesmer 1929; Frey 1960, 1964). A systematic approach to the

Communicated by F. Bittmann.

Lyudmila S. Shumilovskikh

shumilovskikh@gmail.com

1 Department of Palynology and Climate Dynamics, GeorgAugust-University of Göttingen, Wilhelm-Weber-Str. 2a, 37073 Göttingen, Germany

2 Tomsk State University, Lenin Ave 36, Tomsk, Tomsk Oblast, Russia 634050

3 Lower Saxony Institute for Historical Coastal Research, Viktoriastraße 26/28, 26382 Wilhelmshaven, Germany

4 Institute of Biodiversity and Ecosystem Dynamics, University of Amsterdam, P.O. Box 94240, 1090 GE Amsterdam, The Netherlands documentation and taxonomic identification of such objects in Quaternary palynology was started in the 1970 s by the work of the fourth author and his colleagues of the Hugo de Vries-Laboratory at the University of Amsterdam (e.g. van Geel 1972, 1978; Pals et al. 1980; van Geel et al. 1981, 1983a, 1983b, 1989, 2006; Bakker and van Smeerdijk 1982; van der Wiel 1982; Kuhry 1985, 1997). During routine pollen counting, they documented all unknown microfossils under a type number (Type 1, Type 2, Type 3 etc., later known as HdV-1, HdV-2 etc.). Morphological descriptions were provided with microphotographs and known assignment to extant taxa, in combination with discussions on their stratigraphic position and ecological indicator values. The identification was carried out with help of biological literature and consulting specialists in mycology, phycology, zoology and plant anatomy. The known ecological requirements of every identified taxon allow NPPs to be an additional proxy for reconstructing past environments. Even some taxonomically not yet identified types work well as palaeoecological indicators using empirical knowledge.

The usefulness of NPPs is demonstrated by a great variety of new insights into the past (Marret et al. in press). One 
of the most frequently used NPP-groups are the spores of coprophilous fungi, which offer a unique proxy of grazing activities or mammal diet (e.g. Gill et al. 2009; van Geel et al. 2011b; Basumatary and McDonald 2017; van Asperen et al. 2021). Algal palynomorphs, zoological microfossils, and many fungal spores provide information on former local processes like natural and human-induced fire, hydrological conditions and erosion processes (Kuhry 1997; van Geel and Aptroot 2006; Montoya et al. 2010; van Geel et al. 2011a; Kołaczek et al. 2013; Schlütz and Shumilovskikh 2013; Shumilovskikh et al. 2015a, b, 2017, 2021; McCarthy et al. 2021; Mudie et al. 2021). In geoarchaeology, NPPs contribute to a more holistic view of the past (Brinkkemper and van Haaster 2012; Revelles et al. 2016; Shumilovskikh and van Geel 2020; Shumilovskikh and Schlütz 2021).

The systematic approach of NPP documentation led to a strong development in the field of palaeoecology over the last 50 years. Based on a review of classical NPP literature published between 1972 and 2011, Miola (2012) provided a list of recorded Quaternary NPPs and proposed a uniform acronym system. Meanwhile, more than 1,600 classified NPP-types exist, making it difficult to maintain an overview. Morphological identification of NPP-types is based mainly on published images. Due to journal publication rights, some restriction in the use and re-publishing of original images exists. Difficulties in access to literature and images can easily lead to incorrect identifications and may result in questionable palaeoecological interpretations.

In order to gather and sort the available information on NPPs spread over numerous publications and to assist correct identification, we created the on-line resource NonPollen Palynomorphs Image Database (NPP-ID) in 2016.

\section{Non-Pollen Palynomorph Image Database}

The NPP-ID is a platform for sharing information on NPPs for research and education. The platform functions as a research project with the goal of enabling free data sharing and open access to information on NPP-types. While numerical data can be stored in open access repositories like PANGAEA or Neotoma, the NPP-ID provides a means of sharing the definition of the underlying NPP taxa in a similarly standardised way. Due to restrictions caused by publication rights, sharing of some published images is possible only within a defined group of researchers. The NPP-ID research group is organized for this purpose, and registration is needed for full access.

\section{Research group}

The NPP-ID is operating as an open research project. All members may use the NPP-ID content for scientific and educational purposes. The current goals of the NPP research group are: (1) storage of NPP images from the community for open access; (2) structuring of information on NPPs; and (3) revision of and assistance with NPP identifications.

Experienced palynologists are invited to contribute by submitting their own original microphotographs or drawings and background information of newly published or already established NPPs. All rights to the submitted images remain with the submitter. After a short evaluation, images are added to the NPP-ID under the Creative Commons license CC BY-NC-ND (http://creativecommons.org/licenses/by-nc$\mathrm{nd} / 4.0 /$ ). The contributors are credited in the image captions unless they explicitly choose not to be.

\section{Webpage}

The NPP-ID webpage (https://nonpollenpalynomorphs.tsu. $\mathrm{ru} /$ ) also provides information on current publications and upcoming events related to NPP research (Fig. 1). It offers definitions and descriptions of major NPP-groups. Users can easily find the acronym table and access the database in form of an NPP image gallery or an NPP list. A growing list of NPP publications, and links to related databases facilitate further studies. Images can be contributed to the NPP-ID through the homepage.

\section{Organisation of the database}

The NPP-ID platform shares all kinds of practical information on published NPPs. It is designed for research and educational purposes within the scientific and education communities. The following information is provided for the individual types: acronym and number (e.g. HdV-14); latest known or supposed affiliation to an extant genus or species (e.g. Meliola ellisii); higher related taxonomic grouping; morphological description; palaeoecological context of findings; original taxonomical affiliations in chronological order; ecological information on affiliated taxa; map of NPP records; first publication; reference list of cited materials. Acronyms correspond to the NPP list started by Miola (2012) and extended by later publications. For NPPs published without a type number, an artificial acronym NN (no number) is created. A search function with filters based on simple morphological characteristics (Coles 1990) is available to navigate the database.

\section{Technical information}

The website https://nonpollenpalynomorphs.tsu.ru/ is hosted by the Tomsk State University and works on a PHP server and the database is set up in MySQL ${ }^{\mathrm{TM}}$. Webpages are written with help of HTML, CSS, JS, jQuery and Bootstrap, and planned to be refactored with React.js to provide a more 


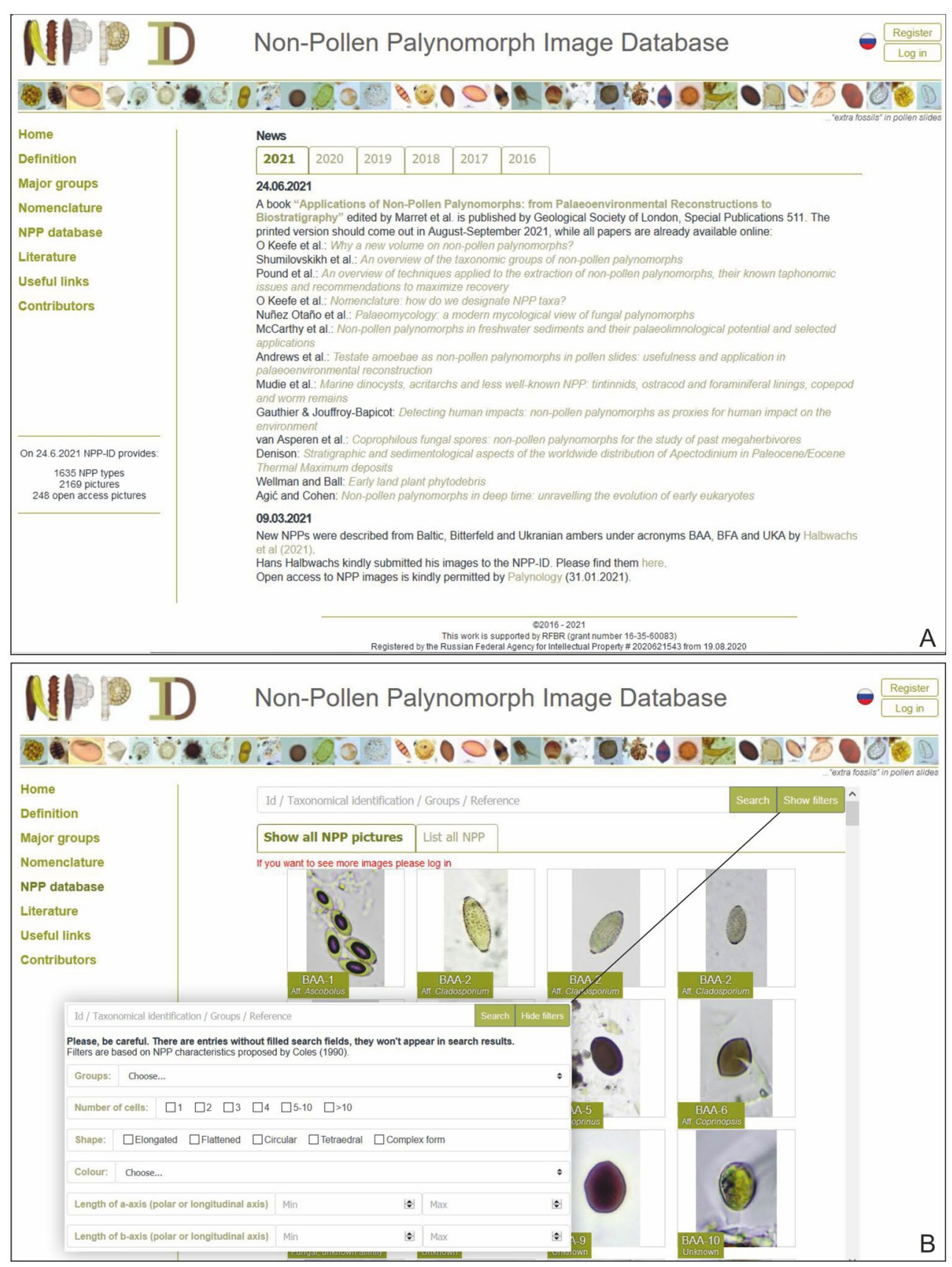

Fig. 1 Screenshots of the Non-Pollen Palynomorph Image Database (NPP-ID; https://nonpollenpalynomorphs.tsu.ru/): A homepage; B search function in the database with filters

modern user experience. The information on NPPs is organized in several related tables (Fig. 2).

\section{Access to the database}

The access to NPP-ID is open to every user of the internet. Due to journal licence politics, access to some original pictures and information requires registration with the NPP-ID research project.
(1) Open access to the NPP-ID provides original descriptions of the NPPs, open access microphotographs/ drawings, a map showing the geographical position of related records and all references. The available data of the NPP-ID are free to use for non-commercial purposes under the Creative Commons license CC BY-NCND (http://creativecommons.org/licenses/by-nc-nd/4. $0 /)$. 


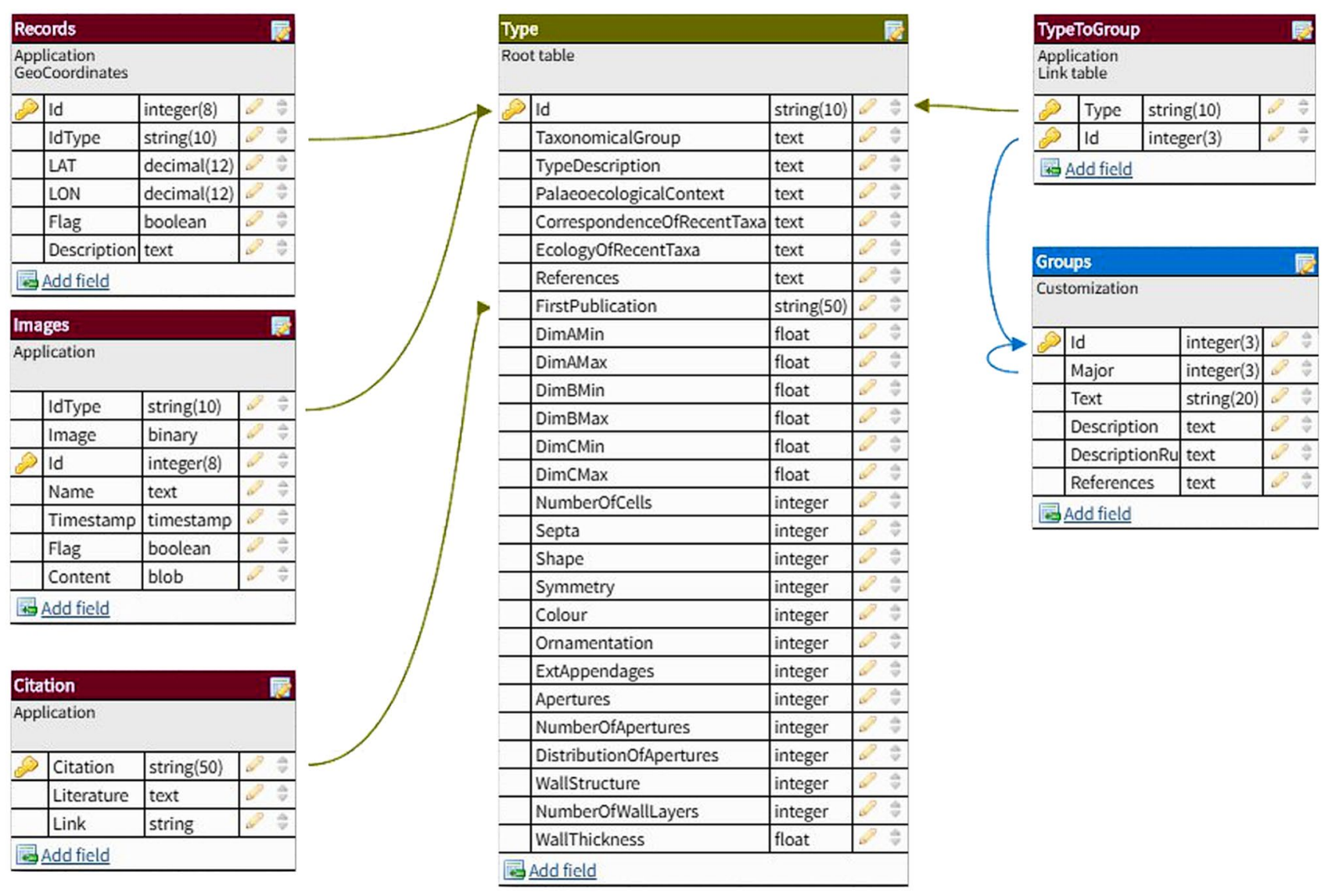

Fig. 2 Internal structure of the Non-Pollen Palynomorph Image Database

(2) Registration additionally offers the microphotographs from published literature and palaeoecological information provided therein, affiliation to taxonomical groups, and their ecology. Registered users can upload their microphotographs to the NPP-ID. Discussion on types and help in identification within the NPP research group can be addressed to all registered users.

For all users of (1) and (2) the common ethics regarding citing of scientific publications and co-authorship apply.

\section{Perspectives of the NPP-ID}

Up to now, the NPP-ID research group consists more than 200 registered scientists and the database offers information on 1,635 NPP-types including 2,169 images. About 10\% of the images are open access. They have been submitted by research group members or were published in journals under Creative Commons licences.

Progress in the development of the NPP-ID is regularly presented at international meetings such as the VII and
VIII Workshops on Non-Pollen Palynomorphs in 2017 in Liverpool (UK) and 2019 in Barcelona (Spain), the 10th European Palaeobotany \& Palynology Conference in Dublin (Ireland) in 2018, and the XX INQUA Congress in Dublin (Ireland) in 2019.

We encourage palynologists to contribute to the further growth of the information stored in NPP-ID by uploading own data, such as microphotographs and descriptions. The best way to do it is to announce submissions of microphotographs to the NPP-ID during publication submission. For this, the authors should provide a statement in their manuscript: "All photos have been uploaded to the Non-Pollen Palynomorphs Image Database (https://nonpo llenpalynomorphs.tsu.ru/) and are free to use for non-commercial purposes under the CC BY-NC-ND licence'. The NPPs will appear online when the manuscript is accepted. Contributors will be acknowledged by co-authorship in publications on updates of the NPP-ID.

Acknowledgements We acknowledge Akhmet Gafarov for technical assistance in the programming of the database, and Monika Schmidt and Svea Lina Jahnk for uploading information on NPPs from literature. Thomas Giesecke and Laura Sutcliffe are acknowledged for checking the English. 
Author contributions LS, ES, FS, BvG provide equal contribution for conceptualisation, LS made the first draft and visualisation, ES, FS, $\mathrm{BvG}$ provided review \& editing.

Funding Open Access funding enabled and organized by Projekt DEAL. The work was partially supported by Russian Foundation for Basic Research (Grant 16-35-60083) and Deutsche Forschungsgemeinschaft (Grants 391893066 and 422265568).

Availability of data and material Non-Pollen Palynomorphs Image Database (http://nonpollenpalynomorphs.tsu.ru/).

Open Access This article is licensed under a Creative Commons Attribution 4.0 International License, which permits use, sharing, adaptation, distribution and reproduction in any medium or format, as long as you give appropriate credit to the original author(s) and the source, provide a link to the Creative Commons licence, and indicate if changes were made. The images or other third party material in this article are included in the article's Creative Commons licence, unless indicated otherwise in a credit line to the material. If material is not included in the article's Creative Commons licence and your intended use is not permitted by statutory regulation or exceeds the permitted use, you will need to obtain permission directly from the copyright holder. To view a copy of this licence, visit http://creativecommons.org/licenses/by/4.0/.

\section{References}

Bakker R, van Smeerdijk DG (1982) A palaeoecological study of a Late Holocene section from 'Het Ilperweld', W. Netherlands. Rev Palaeobot Palynol 36:95-163

Basumatary SK, McDonald HG (2017) Coprophilous fungi from dung of the Greater One-Horned Rhino in Kaziranga National Park, India and its implication to paleoherbivory and paleoecology. Quat Res 88:14-22

Brinkkemper O, van Haaster H (2012) Eggs of intestinal parasites whipworm (Trichuris) and mawworm (Ascaris): Non-pollen Palynomorphs in archaeological samples. Rev Palaeobot Palynol 186:16-21

Coles GM (1990) A note on the systematic recording of organic-walled microfossils (other than pollen and spores) found in archaeological and Quaternary palynological preparations. Circaea 7:103-111

Frey DG (1960) The ecological significance of Cladoceran remains in lake sediments. Ecology 41:684-699

Frey DG (1964) Remains of animals in Quaternary lake and bog sediments and their interpretation. Ergebnisse der Limnologie 2:1-114

Gill JL, Williams JW, Jackson ST, Lininger KB, Robinson GS (2009) Pleistocene megafaunal collapse, novel plant communities, and enhanced fire regimes in North America. Science 326:1,100-1,103

Hesmer H (1929) Mikrofossilien in Torfen. Palaeontol Z 11:245-257

Kołaczek P, Zubek S, Błaszkowski J, Mleczko P, Margielewski W (2013) Erosion or plant succession-how to interpret the presence of arbuscular mycorrhizal fungi (Glomeromycota) spores in pollen profiles collected from mires. Rev Palaeobot Palynol 189:29-37

Kuhry P (1985) Transgressions of a raised bog across a coverstand ridge originally covered with an oak-lime forest. Rev Palaeobot Palynol 44:313-353

Kuhry P (1997) The palaeoecology of a treed bog in western boreal Canada: a study based on microfossils, macrofossils and physicchemical properties. Rev Palaeobot Palynol 96:183-224

Marret F, O'Keefe J, Osterloff P, Pound M, Shumilovskikh L (in press) Applications of Non-pollen Palynomorphs: from palaeoenvironmental reconstructions to biostratigraphy. Geological Society, London. (Special Publications)

McCarthy FMG, Pilkington PM, Volik O, Heyde A, Cocker SL (2021) Non-pollen Palynomorphs in freshwater sediments and their palaeolimnological potential and selected applications. In: Marret F, O'Keefe J, Osterloff P, Pound M, Shumilovskikh L (eds) Applications of Non-pollen Palynomorphs: from palaeoenvironmental reconstructions to biostratigraphy. Geological Society, London, p 511. https://doi.org/10.1144/SP511-2020-109. (Special Publications)

Miola A (2012) Tools for Non-pollen Palynomorphs (NPPs) analysis: a list of Quaternary NPP types and reference literature in English language (1972-2011). Rev Palaeobot Palynol 186:142-161

Montoya E, Rull V, van Geel B (2010) Non-pollen Palynomorphs from surface sediments along an altitudinal transect of the Venezuelan Andes. Palaeogeogr Palaeoclimatol Palaeoecol 297:169-183

Mudie P, Marret F, Gurdebeke PR, Hartman JD, Reid PC (2021) Marine dinocysts, acritarchs and less well-known NPP: tintinnids, ostracod and foraminiferal linings, copepod and worm remains. In: Marret F, O'Keefe J, Osterloff P, Pound M, Shumilovskikh L (eds) Applications of Non-pollen Palynomorphs: from palaeoenvironmental reconstructions to biostratigraphy. Geological Society, London, p 511. https://doi.org/10.1144/ SP511-2020-55. (Special Publications)

Pals JP, van Geel B, Delfos A (1980) Palaeoecological studies in the Klokkeweel bog near Hoogkarspel (prov. of Noord-Holland). Rev Palaeobot Palynol 30:371-418

Revelles J, Burjachs F, van Geel B (2016) Pollen and Non-pollen Palynomorphs from the Early Neolithic settlement of La Draga (Girona, Spain). Rev Palaeobot Palynol 225:1-20

Rudolph K (1917) Untersuchungen über den Aufbau Böhmischer Moore: I. Aufbau und Entwicklungsgeschichte Südböhmischer Moore. Abh KK Zool-Bot Ges Wien 9:1-116

Schlütz F, Shumilovskikh LS (2013) On the relation of Potamomyces armatisporus to the fossil form-type Mediaverrunites and its taxonomical and ecological implications. Fungal Ecol 6:309-315

Shumilovskikh LS, Schlütz F (2021) Nichtpollen Palynomorphe. In: Stolz C, Miller CA (eds) Geoarchäologie. Springer Spektrum, Berlin, pp 17-19 (in German)

Shumilovskikh LS, van Geel B (2020) Non-pollen Palynomorphs. In: Henry AG (ed) Handbook for the analysis of micro-particles in archaeological samples. Springer, Berlin, pp 65-94. https://doi. org/10.1007/978-3-030-42622-4_4

Shumilovskikh LS, Schlütz F, Achterberg I, Bauerochse A, Leuschner HH (2015a) The development of the raised bog "Borsteler Moor" (Lower Saxony, Germany) based on Non-pollen Palynomorph data. Studia Quat 32:5-18

Shumilovskikh LS, Schlütz F, Achterberg I, Kvitkina A, Bauerochse A, Leuschner HH (2015b) Pollen as nutrient source in Holocene ombrotrophic bogs. Rev Palaeobot Palynol 221:171-178

Shumilovskikh LS, Ferrer A, Schlütz F (2017) Non-pollen Palynomorphs notes: 2. Holocene record of Megalohypha aqua-dulces, its relation to the fossil form genus Fusiformisporites and its association with lignicolous freshwater fungi. Rev Palaeobot Palynol 246:167-176

Shumilovskikh LS, O'Keefe JMK, Marret F (2021) An overview of the taxonomic groups of NPPs. In: Marret F, O'Keefe J, Osterloff P, Pound M, Shumilovskikh L (eds) Applications of Non-pollen Palynomorphs: from palaeoenvironmental reconstructions to biostratigraphy. Geological Society, London, p 511. https://doi. org/10.1144/SP511-2020-65. (Special Publications)

Van Asperen EN, Perrotti A, Baker A (2021) Coprophilous fungal spores: Non-pollen Palynomorphs for the study of past megaherbivores. In: Marret F, O'Keefe J, Osterloff P, Pound M, Shumilovskikh L (eds) Applications of Non-pollen Palynomorphs: from 
palaeoenvironmental reconstructions to biostratigraphy. Geological Society, London, p 511. https://doi.org/10.1144/SP511-202041. (Special Publications)

Van der Wiel AM (1982) A palaeoecological study of a section from the foot of the Hazendonk (Zuid-Holland), based on the analysis of pollen, spores and macroscopic remains. Rev Palaeobot Palynol 38:35-90

Van Geel B (1972) Palynology of a section from the raised peat bog "Wietmarscher Moor", with special reference to fungal remains. Acta Bot Neerl 21:261-284

Van Geel B (1978) A palaeoecological study of Holocene peat bog sections in Germany and the Netherlands, based on the analysis of pollen, spores and macro- and microscopic remains of fungi, algae, cormophytes and animals. Rev Palaeobot Palynol 25:1-120

Van Geel B, Aptroot A (2006) Fossil ascomycetes in Quaternary deposits. Nova Hedwigia 82:313-329

Van Geel B, Bohncke SJP, Dee H (1981) A palaeoecological study of an upper Late Glacial and Holocene sequence from 'De Borchert', The Netherlands. Rev Palaeobot Palynol 31:367-448

Van Geel B, Bos JM, Pals JP (1983a) Archaeological and palaeoecological aspects of a medieval house terp in a reclaimed raised bog area in North Holland. Ber Rijksd Oudheidk Bodemonderz 33:419-444

Van Geel B, Hallewas DP, Pals JP (1983b) A Late Holocene deposit under the Westfriese Zeedijk near Enkhuizen (Prov. of
Noord-Holland, The Netherlands): palaeoecological and archaeological aspects. Rev Palaeobot Palynol 38:269-335

Van Geel B, Coope GR, van der Hammen T (1989) Palaeoecology and stratigraphy of the Lateglacial type section at Usselo (The Netherlands). Rev Palaeobot Palynol 60:25-129

Van Geel B, Aptroot A, Mauquoy D (2006) Sub-fossil evidence for fungal hyperparasitism (Isthmospora spinosa on Meliola ellisii, on Calluna vulgaris) in a Holocene intermediate ombrotrophic bog in northern-England. Rev Palaeobot Palynol 141:121-126

Van Geel B, Gelorini V, Lyaruu A et al (2011a) Diversity and ecology of tropical African fungal spores from a 25,000-year palaeoenvironmental record in southeastern Kenya. Rev Palaeobot Palynol 164:174-190

Van Geel B, Guthrie RD, Altmann JG et al (2011b) Mycological evidence of coprophagy from the feces of an Alaskan Late Glacial mammoth. Quat Sci Rev 30:2,289-2,303

Publisher's Note Springer Nature remains neutral with regard to jurisdictional claims in published maps and institutional affiliations. 